\title{
ARTICLE
}

\section{Europeanism: A Historical View}

\author{
Marius S. Ostrowski ${ }^{1}$ \\ Robert Schuman Centre for Advanced Studies, European University Institute, Florence, Italy \\ marius.ostrowski@eui.eu
}

\begin{abstract}
The ideology of Europeanism - defined as a commitment to the political, economic, and cultural consolidation of the European continent - has undergone major transformations during the twentieth century. Yet the study of Europeanism has not as yet systematically examined the range of conceptual meanings that the various strands of the Europeanist ideological family exhibit. Instead, Europeanism has typically been treated either ahistorically as a set of desirable social ideals and values, or reductively as a quality exclusively associated with European institutions in their current form. Both obscure the fundamental, wide-ranging debates over the nature of 'Europe' and 'Europeanness' that have shaped the substantive development of Europeanist ideologies over the last century. This article maps out the key areas of conceptual contestation that are consistently shared by all Europeanisms regarding the boundaries of Europe, the degree of European consolidation, and how 'Europeanisation' is to be realised.
\end{abstract}

The turn of the twentieth century is often seen as an unusually fertile period of ideological innovation. This perception is driven by several developments in three of the major ideological families, whose transformative societal significance in some cases reached literally cataclysmic proportions. First, with its earliest origins lying in the 1870s, came the state-welfarist 'social turn' within liberalism, conceived as a direct repudiation of its laissez-faire 'classical' guise; second, commencing in the $1880 \mathrm{~s}$, the rise of fascism and Christian democracy as competing efforts to recast the concepts and values of conservatism for a new era of mass popular-democratic mobilisation; and third, from the 1890s, the emergence and institutionalisation (partisan as well as geographic) of a schism between statist-reformist social democracy and councilist-revolutionary communism as offshoots of socialism. Yet in parallel to - and under the influence of - these macro-ideological developments, this period also represented a key developmental moment for a series of smaller, more 'thin-centred' micro-ideologies. Nationalism took on new forms, often shorn of its democratic and anti-imperial connotations; feminism consolidated its alliances with middle- and working-class projects of empowerment; and a plethora of movements crystallised around emancipatory ethnocultural and religious ideologies on the one hand, and racist and discriminatory ideologies on the other.

The same period of ideological upheaval also saw the first modern emergence of the movements and organisations whose primary aspiration is the consolidation of the European continent. Their various political, economic, and cultural perspectives and priorities are encapsulated in different articulations of another distinct micro-ideology: 'Europeanism'. The ideology of Europeanism has undergone major transformations over the course of the twentieth century: sudden moments and prolonged periods of revision, reappropriation, (re)invention, de- and reconstruction, de- and

1 Early versions of this article were presented to sessions of the 'Europe in the World' research seminar and Robert Schuman Centre seminar series at the European University Institute in 2020-21. I am extremely grateful to Amedeo Arena, Graham Avery, Catherine Gegout, Philipp Genschel, Julia Gray, Ulrich Krotz, Robin Markwica, Alyson Price, Maarten Vink, and all the attendees of both seminars for their helpful recommendations and advice. I am also indebted to the three anonymous reviewers for Contemporary European History as well as the editor, Quinn Slobodian, for their insightful and invaluable suggestions for improvement.

(c) The Author(s), 2021. Published by Cambridge University Press. This is an Open Access article, distributed under the terms of the Creative Commons Attribution licence (https://creativecommons.org/licenses/by/4.0/), which permits unrestricted re-use, distribution, and reproduction in any medium, provided the original work is properly cited. 
recontextualisation. Yet despite this rich history of evolving historical manifestations, the study of Europeanism as an ideology has yet to fully capture the synchronic and diachronic variety of meaning it exhibits. This article argues that the study of Europeanism is characterised by an excessive ahistoricism and a narrow reductionism, which distort the prevailing characterisation of Europeanist ideology. Together, these tendencies threaten to stymy a full appreciation of the richness and diversity of Europeanism as a discursive framework and mobilising social force. This article sets out an alternative approach, which takes Europeanism seriously as the collective term for a set of ideological strands that share a 'family resemblance' due to their overlapping conceptual patterning. It traces the explosion of Europeanist ideological activity that took place over the course of the twentieth century, and focuses on the sites of conceptual contestation between different historical Europeanisms over 'Europe' and 'Europeanness' as their constitutive ideological subject.

\section{Europeanism as an Ideology}

Although ideas of European unification and integration can draw on a significant prehistory, with individual precursors lying as far back as the Enlightenment or even the Renaissance, the crystallisation of these ideas into a determinate ideological form is indisputably a modern phenomenon. ${ }^{2}$ Its background was the intensifying struggle between contrary pulls of nationalism and internationalism in European diplomacy, trade, commerce, art, and literature, punctuated by outbreaks of unprecedented violence and destruction in the First and Second World Wars. ${ }^{3}$ From this point of initial crystallisation, Europeanist ideology evolved during the twentieth century in a series of distinct phases; in each phase, Europeanist ideological output was more-or-less closely and explicitly influenced by articulations of the major and emergent ideologies of the time. The first third of the century saw the rise of a hitherto unprecedented series of self-conscious exponents of Europeanist ideology: the emergence of ever more detailed proposals for European unification by Europeanist thinkers, conservative and socialist, with speculative fascist and communist variants, followed by the first movements and groups to advocate for their realisation. ${ }^{4}$ The middle third saw significant advances in the founding of Europeanist organisations, dominated by Christian Democrats and Social Democrats, which fuelled the flurry of treaties between national governments that established the first European tier of institutions. ${ }^{5}$ The final third of the twentieth century, running into the early twenty-first, was

2 Gerard Delanty, Inventing Europe: Idea, Identity, Reality (Basingstoke: Palgrave Macmillan, 1995), 16-29; Jean-Baptiste Duroselle, L'Idee d'Europe dans l'histoire (Paris: Denoël, 1965); Anthony Pagden, The Idea of Europe: From Antiquity to the European Union (Cambridge: Cambridge University Press, 2010), 33-138; Wolfgang Schmale, Geschichte und Zukunft der Europäischen Identität (Stuttgart: W. Kohlhammer, 2008), 43-60, 76-99; Kevin Wilson and Jan van der Dussen, eds., The History of the Idea of Europe (Abingdon: Routledge, 1995), 1-59.

3 Antonin Cohen, 'Why Call It a "European Community"? Ideological Continuities and Institutional Design of Nascent European Organisations', Contemporary European History, 27, 2 (2018), 326-44; David Stevenson, 'The First World War and European Integration', International History Review, 34, 4 (2012), 841-63; Peter M.R. Stirk, A History of European Integration Since 1914 (New York: Continuum, 1997), 39-50; Wilson and van der Dussen, History of the Idea of Europe, 64-84.

4 Raimund Bauer, The Construction of a National Socialist Europe during the Second World War: How the New Order Took Shape (Abingdon: Routledge, 2019); Monica Fioravanzo, 'The Fascist and the National Socialist Concept of Europe (1939-1943)', Vierteljahrshefte für Zeitgeschichte, 58, 4 (2010), 509-41; Dieter Gosewinkel, ed., Anti-liberal Europe: A Neglected Story of Europeanization (New York: Berghahn Books, 2014); Davide Rodogno, Il nuovo ordine mediterraneo: Le politiche di occupazione dell'Italia fascista in Europa (1940-1943) (Turin: Bollati Boringhieri, 2003); Michael Lawrence Smith and Peter M.R. Stirk, eds., Making the New Europe: European Unity and the Second World War (London: Bloomsbury, 2016); Peter M.R. Stirk, ed., European Unity in Context (London: Bloomsbury, 2016); Yongseon Yun, 'Trotsky's Understanding of “The United States of Europe”, Korean Society for European Integration, 10, 1 (2019), 1-22.

5 Paolo Acanfora, 'The Italian Christian Democratic Party within the International Christian Democratic Organizations: Nationalism, Europeanism, and Religious Identity (1947-1954)', Journal of Modern Italian Studies, 15, 2 (2010), 20031; Rosario Forlenza, 'The Politics of the Abendland: Christian Democracy and the Idea of Europe after the Second World War', Contemporary European History, 26, 2 (2017), 261-86; Wolfram Kaiser, Christian Democracy and the Origins of European Union (Cambridge: Cambridge University Press, 2007). 
marked by the steady eclipsing of the old movements as Europeanist ideological leaders by a rapidlygrowing castlist of national governments and European institutions, increasingly tinged by liberal commitments, and finally the rise of movements advocating Europhile and Eurosceptic transformations to Europe's status quo. ${ }^{6}$ Each phase endowed Europeanism with new conceptual interpretations and applications that helped shape the evolution of the Europeanist ideological family right up to the present day.

But the treatment of this Europeanist ideological family in European studies - a subfield that is often methodologically dominated by, and even subsumed into, the social and political sciences has commonly exhibited two problematic tendencies. The first is an at times inadequate sense of the historical contingency and fluidity of Europeanism's conceptual content. ${ }^{7}$ Europeanism is often portrayed as an emergent social property: a set-piece tableau intended to capture an idealised rendering of European perfection. ${ }^{8}$ Statements of 'Europeanist values' typically present them as eternal principles or permanent characteristics that putatively summarise European political, economic, or cultural uniqueness: welfarism, secularism, individual rights, multiculturalism, societal collectivism/communitarianism, multilateralism, sustainability, and a mixture of statism and a market economy. ${ }^{9}$ Each of these has been more-or-less realised in society today, and each of their meanings - as well as their inclusion in the tableau tout court - is considered essentially fixed or at least unchallenged. ${ }^{10}$ At most, there is only a sense that 'Europeanism' can grow in size or become more detailed by absorbing new concepts. ${ }^{11}$ What deserves far greater attention in studies of Europeanism are the often closelyfought, impermanent processes of contestation and decontestation by which these concepts come to enjoy their particular association with 'Europe' and 'Europeanness'. ${ }^{12}$ Similarly, examining the sequence of conscious impositions of meaning on these concepts can help European studies build on historical scholarship about the evolving 'meanings of Europe' to gain a better sense of the plurality and range of diachronic meanings that Europeanism has held. ${ }^{13}$ This can shed clearer light on the richness of Europeanism as an ideology, rather than merely taking at face-value the final outcomes of these historical processes, unearthed from the most recent time-strata of conceptual meaning.

${ }^{6}$ Marco Baldassari, Emanuele Castelli, Matteo Truffelli, and Giovanni Vezzani, eds., Anti-Europeanism: Critical Perspectives Towards the European Union (Cham: Springer, 2020); Thomas Biebricher, 'Europe and the Political Philosophy of Neoliberalism', Contemporary Political Theory, 12, 4 (2013), 338-75; David J. Gerber, 'Constitutionalizing the Economy: German Neo-Liberalism, Competition Law and the "New" Europe', The American Journal of Comparative Law, 42, 1 (1994), 25-84; David Schäfer, 'A Banking Union of Ideas? The Impact of Ordoliberalism and the Vicious Circle on the EU Banking Union', Journal of Common Market Studies, 54, 4 (2016), 961-80.

7 John Gillingham, 'A Theoretical Vacuum: European Integration and Historical Research Today', Journal of European Integration History, 14, 1 (2008), 27-35; Fabrice Larat, 'Present-ing the Past: Political Narratives on European History and the Justification of EU Integration', German Law Journal, 6, 2 (2005), 273-90.

8 Duroselle, L'Idee d'Europe; Melissa Pine, 'European Integration: A Meeting Ground for History and Political Science? A Historian Responds to Andrew Moravcsik', Journal of European Integration History, 14, 1 (2008), 87-105; Paul Taylor, The End of European Integration: Anti-Europeanism Examined (Abingdon: Routledge, 2008), 135-46.

9 John M. Headley, The Europeanization of the World: On the Origins of Human Rights and Democracy (Princeton, NJ: Princeton University Press, 2007); Daniel Levy, Max Pensky, and John Torpey, eds., Europe, New Europe, Core Europe (London: Verso, 2005); John McCormick, Europeanism (Oxford: Oxford University Press, 2010), 217-20.

10 Richard Bellamy and Joseph Lacey, eds., Political Theory and the European Union (Abingdon: Routledge, 2017); Nikola Petrović, 'EU Ideology', Innovation: The European Journal of Social Science Research, 29, 1 (2016), 56-76.

11 Mark Gilbert, Surpassing Realism: The Politics of European Integration since 1945 (Lanham, MD: Rowman \& Littlefield, 2003); Mark Gilbert, 'Narrating the Process: Questioning the Progressive Story of European Integration', Journal of Common Market Studies, 46, 3 (2008), 641-62; John Gillingham, European Integration 1950-2003 (Cambridge: Cambridge University Press, 2003); John Gillingham, Design for a New Europe (Cambridge: Cambridge University Press, 2006).

12 Quincy Cloet, 'Two Sides to Every Story(Teller): Competition, Continuity and Change in Narratives of European Integration', Journal of Contemporary European Studies, 25, 3 (2017), 291-306.

13 Mikael af Malmborg and Bo Stråth, eds., The Meaning of Europe: Variety and Contention within and among Nations (Oxford: Berg, 2002); Claudia Wiesner and Meike Schmidt-Gleim, eds., The Meanings of Europe: Changes and Exchanges of a Contested Concept (Abingdon: Routledge, 2014), 1-32. 
Above all, what needs to be centred in this analysis are the major events and changes in power configurations that fuelled and underpinned these processes and led to the evolutions in the meaning of Europeanism.

The second tendency is an insufficiently-deconstructed essentialism towards the role of actually-existing institutional realisations of Europeanism for its conceptual content. ${ }^{14}$ Especially in the social-scientific literature, but also in many historical accounts of the 'prehistory' of European integration, Europeanism tends to be identified specifically with the family of prevailing European political, economic, and cultural institutions. Such an identification sacrifices any sense that, as an a priori abstract constellation of concepts, it can embed a multitude of possibilities for realisation - i.e. 'many Europes', each reflecting different aspects of European regional or demographic distinctiveness and value. ${ }^{15}$ This tendency carries a connotation of 'teleological' inevitability about the specific current path of institutionalisation, and of an inexorable path to which Europeans are subjected rather than a process that Europeans subjectively continually (re)make. ${ }^{16}$ In extremis, the shift away from ideal potential towards practical actuality is so pronounced as to restrict the horizon of Europeanist possibility to a pure status quo defence of the European Union's current institutions - and to frame 'Europeanisation' as exclusively describing increases in their competences. ${ }^{17}$ In this context, analyses of Europeanism must be careful not to reinforce or perpetuate an imposed decontestation that attributes meaning to Europeanism only through its logical or contextual adjacency to actually-existing European or national bodies. A full ideological analysis of Europeanism entails lifting the strict limits that institutionalisation deliberately seeks to impose on the horizons of synchronic meaning, by using selective realisation to favour certain otherwise-abstract interpretations at the expense of others. If it does not do so, European studies essentially cedes the turf of Europeanist ideologisation to the context provided by the status quo of European power configurations, at the expense of considering the often fantastical and irreducibly counter-hegemonic forms that Europeanism has taken over its history.

In order to counteract these tendencies, European studies - especially but by no means exclusively in its social-scientific guise - needs to adopt a 'longitudinal' account of Europeanism as an ideology, drawing on recent developments in the intellectual history and historiography of European integration. The onus for this account lies on capturing the changing structural configuration of Europeanism's constituent concepts as well as the cumulative and (dis)continuous development of these concepts' meanings, and contextualising these meanings to the intentions with which they were introduced within different Europeanist intellectual traditions. ${ }^{18}$ Specifically, it needs to recentre 'Europe' or 'Europeanness' (not 'European values' or the European Union) as the constitutive subject of Europeanism within its conceptual content - i.e. the place(s) and people(s) around which the Europeanist ideological family is built, and which act as the unique loci and objects of contestation for Europeanism's conceptual meaning. The following analysis outlines the historical evolution of the core concepts of Europeanist ideology, with particular focus on the sites of conceptual contestation

\footnotetext{
14 Kiran Klaus Patel, 'Widening and Deepening? Recent Advances in European Integration History', Neue Politische Literatur, 64, 2 (2019), 327-57; Peter Pichler, '(Finally) Beyond "Ever Closer Union" and EU Centrism? A Review Essay on the Most Recent Trends in European Studies and European Integration History', European History Quarterly, 50, 1 (2020), 128-36.

15 Kiran Klaus Patel, 'Provincialising European Union: Co-operation and Integration in Europe in a Historical Perspective', Contemporary European History, 22, 4 (2013), 649-73; Donald J. Puchala, 'Europeans and Europeanism in 1970', International Organization, 27, 3 (1973), 387-92; Donald J. Puchala, 'Europeanism in the Nineteen Eighties', Il Politico, 51, 2 (1986), 181-97; Wiesner and Schmidt-Gleim, Meanings of Europe, 3-4; Wilson and van der Dussen, History of the Idea of Europe, 140-1.

16 Étienne Balibar, 'The Rise and Fall of the European Union: Temporalities and Teleologies', Constellations, 21, 2 (2014), 202-12; Mary Farrell, Stefano Fella, and Michael Newman, eds., European Integration in the 21st Century: Unity in Diversity? (London: SAGE, 2002), 15-28; Gilbert, Surpassing Realism; Gilbert, 'Narrating the Process'.

17 Ramona Coman, Thomas Kostera, and Luca Tomini, eds., Europeanization and European Integration: From Incremental to Structural Change (Basingstoke: Palgrave Macmillan, 2014); Robert Harmsen and Thomas M. Wilson, eds., Europeanization: Institution, Identities and Citizenship (Amsterdam: Rodopi, 2000).

18 Cloet, 'Two Sides to Every Story(Teller)', 293.
} 
between different rival Europeanisms. It starts by examining changing historical views of the boundaries of European consolidation: which places and peoples count as members of 'Europe' and how they should be amalgamated, as well as how the new European entity should behave towards the places and peoples beyond these boundaries. The analysis then moves onto the evolving ideological conceptions of the degree of consolidation: the areas of social life that should be prioritised for 'Europeanisation', the concrete consolidated forms that such Europeanisation should take, and the range of different European entities that are to take shape as a result. Finally, it discusses different historical approaches towards the strategic sequence and speed at which European consolidation is to be realised, and whether its final achievement marks a teleological point of closure for Europeanist ideological aspirations.

\section{The Boundaries of European Consolidation}

In ideological disputes over Europe's boundaries, the seminal question concerns which parts of the continent are included and excluded from the definition of 'Europe'. ${ }^{19}$ Since the inception of the modern Europeanist debate, relations between France and Germany (especially post-war rapprochement) have been the fulcrum on which prospects for European unification have turned; around them was grouped a consistent set of countries - the Benelux and Italy - that together with them constituted 'core Europe' as the 'continentalist' epicentre for projects of European unification. ${ }^{20}$ But beyond this solidly Western-European 'core', there has been greater dissensus over the eligibility of countries from other more 'peripheral' regions for inclusion, and the conditions that would have to be met for this to happen: in descending order of eligibility, Scandinavia, Iberia, Eastern/Southeastern Europe, Britain, Turkey, and Russia. ${ }^{21}$

Historically, Europeanisms have exhibited many competing tendencies to 'naturalise' the borders of 'Europe' in completely different ways. ${ }^{22}$ Some were more restrictive, drawing the borders of 'true Europe' narrowly, as with the rival projects of Mitteleuropa ('Central Europe') versus the Franco-British Union, or the later Nazi transmogrification of 'Western' European solidarity into a campaign against perceived 'Eastern' territorial enemies 'without' and racial and ideological enemies 'within'. ${ }^{23}$ Others were expansive, positing homologies with one or more of Europe's constitutive others: Euro-Americanism-Atlanticism or Eurasianism, rival decontestations of the Global North playing on different economic-political-cultural similarities and shared histories; or Eurafricanism, uniting the 'middle' longitudes between the 'Anglo-Saxon' Americas and 'Oriental' Asia. ${ }^{24}$ Ultimately, the intermediate 'continentalist' conception of Europe, and especially of its Western

\footnotetext{
19 Wilson and van der Dussen, History of the Idea of Europe, 103-11.

20 Delanty, Inventing Europe, 30-47; Pierre-Henri Laurent, 'Beneluxer Economic Diplomacy and the Creation of Little Europe, 1945-1950', Journal of European Integration, 10, 1 (1986), 23-37; Wilfried Loth, 'Die "Kerneuropa”-Idee in der europäischen Diskussion', Journal of European Integration History, 21, 2 (2015), 203-16.

21 Wolfram Kaiser, 'Culturally Embedded and Path-Dependent: Peripheral Alternatives to ECSC/EEC “Core Europe” since 1945’, Journal of European Integration History, 7, 2 (2001), 11-36.

22 Gunnar Folke Schuppert, Ingolf Pernice, and Ulrich Haltern, eds., Europawissenschaft (Baden-Baden: Nomos, 2005), 275-98.

23 Hans-Dietrich Schultz and Wolfgang Natter, 'Imagining Mitteleuropa: Conceptualisations of "Its" Space In and Outside German Geography', European Review of History, 10, 2 (2003), 273-92; Stevenson, 'The First World War'; David Weigall and Peter M.R. Stirk, eds., The Origins and Development of the European Community (New York: St Martin's Press, 1992), 4-37.

24 Delanty, Inventing Europe, 84-99; Piotr Dutkiewicz and Richard Sakwa, Eurasian Integration - The View from Within (Abingdon: Routledge, 2015); Michael Gehler and Silvio Vietta, eds., Europa - Europäisierung - Europäistik: Neue wissenschaftliche Ansätze, Methoden, und Inhalte (Vienna: Böhlau, 2010), 381-410; John Halstead, 'Atlantic Community or Continental Drift?', Journal of European Integration, 16, 2-3 (1993), 151-64; Alan K. Henrikson, 'The New Atlanticism: Western Partnership for Global Leadership', Journal of European Integration, 16, 2-3 (1993), 165-91; David Lane and Vsevolod Samokhvalov, The Eurasian Project and Europe: Regional Discontinuities and Geopolitics (Basingstoke: Palgrave Macmillan, 2015); Reinhardt Rummel, 'Atlanticism in a Demanding Context: Cooperative Leadership in the Test', Journal of European Integration, 16, 2-3 (1993), 193-207.
} 
'core', was confirmed by the context of the early Cold War. ${ }^{25}$ The founding members of the European Communities were caught between the Soviet bloc and Austrian neutrality, the continuation of fascism in Spain and Portugal, and a Scandinavia that until the 1970s was still hedging its bets on a 'Nordic' route to regional consolidation. ${ }^{26}$ With the possible exception of Britain and Ireland, the 'core six' at the time were the only available exemplars of (1) the Christian-and-Social-Democratic form of the post-Second World War right-left economic bargain, (2) electoral-parliamentary democratic politics, and (3) a shared post-Enlightenment (Christian) confessional-secularist cohabitation. ${ }^{27}$ In other words, the European 'core' was not just a geographical label but also a political, economic, and cultural signifier. Debates over extending 'Europe' - from the rehabilitation of post-Second World War Germany and the longstanding French veto on including Britain (and Ireland and Denmark in solidarity) to the question of southern and eastern enlargement - correlate with the societal penetration of these or closely-related political, economic, and cultural characteristics. ${ }^{28}$ Similarly, European 'extension' has typically taken place hot on the heels of major changes in countries' social orders where these led to economic liberalisation, democratisation, and an equilibrium point away from either theocracy or religious persecution. Overall, the second half of the twentieth century has seen a softening of the Cold War-era narrow 'kleineuropäisch' (small European) conceptions into a more expansive (even expansionist) 'großeuropäisch' (greater European) logic; in a way, a return to the broad interwar conceptions of 'Europe', which did not operate a 'core-periphery' logic beyond centring the importance of positive Franco-German relations. ${ }^{29}$

Closely aligned with the question of inclusion and exclusion is that of the way in which Europe's constituent parts are to be incorporated into the European entity. Prima facie, the dominant assumption, from proposals for a 'United States of Europe' to mechanisms for EU enlargement to 'candidate countries', has been that a consolidated Europe would take the form of a partnership between European nation-states, agreed via intergovernmental negotiation or plebiscitary endorsement. ${ }^{30}$ Yet the Europeanist ideological family also includes many other models, ranging from conceptions of Europe as a union of alternative spatial or population units - 'peoples', nations, regions, even workers' councils - to those of a more undifferentiated community or even subsumed administrative subunits of a monolithic nation-empire. ${ }^{31}$

25 Delanty, Inventing Europe, 115-29.

26 Michael Gehler, From Saint-Germain to Lisbon: Austria's Long Road from Disintegrated to United Europe 1919-2009 (Vienna: Austrian Academy of Sciences Press, 2020); Johnny N. Laursen and Thorsten B. Olesen, 'A Nordic Alternative to Europe? The Interdependence of Denmark's Nordic and European policies, 1945-1998', Contemporary European History, 9, 1 (2000), 59-92; Oliver Rathkolb, 'Österreich zwischen Neutralität und Allianzfreiheit 19532000', Journal of European Integration History, 7, 2 (2001), 103-26; Gerald Stourzh and Wolfgang Mueller, A Cold War over Austria: The Struggle for the State Treaty, Neutrality, and the End of East-West Occupation, 1945-1955 (Lanham, MD: Lexington Books, 2018).

27 Gustav F. Schmidt, 'Europe and the World', Contemporary European History, 9, 3 (2000), 355-66.

28 Emma De Angelis and Eirini Karamouzi, 'Enlargement and the Historical Origins of the European Community's Democratic Identity, 1961-1978', Contemporary European History, 25, 3 (2016), 439-58; Vincent Dujardin, 'The Failed Attempt to Relaunch the WEU and the Issue of the First Enlargement', Journal of European Integration History, 12, 1 (2006), 25-42.

29 Delanty, Inventing Europe, 130-55; Mikael af Malmborg, 'Swedish Neutrality, the Finland Argument, and the Enlargement of "Little Europe", Journal of European Integration History, 3, 1 (1997), 63-80.

30 Richard Bellamy, A Republican Europe of States: Cosmopolitanism, Intergovernmentalism, and Democracy in the EU (Cambridge: Cambridge University Press, 2019); De Angelis and Karamouzi, 'Enlargement and the Historical Origins'; Schuppert, Pernice, and Haltern, Europawissenschaft, 101-28, 147-76, 613-42, 705-42.

31 Mats Andrén, 'Europe of Nations, Europe without Nationalism', History of European Ideas, 46, 1 (2020), 13-24; Richard Bellamy, “An Ever Closer Union Among the Peoples of Europe": Republican Intergovernmentalism and Democratic Representation within the EU', Journal of European Integration, 35, 5 (2013), 499-516; Eve Hepburn, 'The Rise and Fall of a "Europe of the Regions", Regional and Federal Studies, 18, 5 (2008), 537-55; John Loughlin, "Europe of the Regions" and the Federalization of Europe', Publius, 26, 4 (1996), 141-62; Romain Pasquier, 'The End of a Europe of the Regions?', Politique européenne, 50, 1 (2015), 150-9; Anthony D. Smith, 'A Europe of Nations - or the Nation of Europe?', Journal of Peace Research, 30, 2 (1993), 129-35. 
Especially during the interwar period, ambitious plans circulated among Europeanists to dissolve historical states and even subnational divisions, and wholly redistrict Europe into a series of new 'cantons' or 'provinces' - of which the most radical instantiation was the Nazi construction of Reichsgau and Reichskommissariat administrative divisions across occupied Europe during the Second World War. More concessive attempts to challenge the configuration of nation-states of which Europe consisted tended to see European integration as a second stage of consolidation. They often conceived the first, prerequisite stage as being the integration of macroregions - e.g. 'Danubian' and 'Rhenish' Europe, Britain and France, the Benelux, 'Western Europe', Mitteleuropa, the Międzymorze ('Intermarium') - with later harmonisation and negotiation between these intermediary units used as a stepping-stone to 'full' Europeanisation. But this was abandoned in the actual post-Second World War process of European institution-building, which elided these stages into a single one that cleaved closely to a logic of stringent member-state equality. ${ }^{32}$ This (re)orientation towards methodological nationalism and statism was to a large degree entrenched by the most successful post-Second World War Europeanist movements in the immediate lead-up to the founding treaties of the 1950s. Although transnational by construction, they often emerged from - and stayed differentiated into - 'national' sections, which were sometimes radically opposed on core questions of Europeanisation. ${ }^{33}$

Since their initial formation for the European Communities, the European Council (EUCO), the Council of the EU (CEU), and the European Court of Justice (ECJ) have always been premised on member-state equality; the European Commission (EC) previously reflected member-states' relative populousness by awarding the larger ones an additional commissioner, but even this modest qualification was abandoned in 2004. Only with the introduction of European Parliament (EP) elections in 1976-9 have European institutions gained a non-statist element that reflects alternative geographies such as mesoregions (as EP constituencies) or the continent as a whole. ${ }^{34}$ In general, the EU's territorial expansion has entrenched the logic of expansion through co-opting 'association' and 'partnership', and superficially strengthened the logic of member-state equality. Yet with every enlargement, especially after the sheer number of new members in 2004, this equality has become increasingly fictitious as a reflection of the internal power configurations and strategies of European-level interactions. ${ }^{35}$ Rather, the latest evolution has been an emergent regional logic, whereby originally non-EU groupings such as the Nordic Council, the Baltic Assembly, and the Visegrád Group are being transformed into 'blocs' within intra-European power dynamics.

Once the borders of the European entity are defined, Europeanists next consider the question of what type of agency it should exhibit on the global stage. Running throughout the ideological history of the 'European idea' is the conception of Europe as a defensive bastion: as a protection for European agriculture and industry against the predations of Anglo-American or latterly Chinese capital, for liberal democracy against communist totalitarianism or the authoritarian populism of the 'neonationalist international', or for 'Western civilisation' against racialised putative incursions via the Mediterranean. ${ }^{36}$ But this 'fortress' logic has been consistently contested by Europeanisms that offer

\footnotetext{
32 Antonina Bakardjieva Engelbrekt, Karin Leijon, Anna Michalski, and Lars Oxelheim, eds., The European Union and the Return of the Nation State (Basingstoke: Palgrave Macmillan, 2020); Alan S. Milward, The European Rescue of the Nation State (Abingdon: Routledge, 2000).

33 Wolfgang Kaiser, Brigitte Leucht, and Michael Gehler, eds., Transnational Networks in Regional Integration: Governing Europe 1945-83 (Basingstoke: Palgrave Macmillan, 2010); Malmborg and Stråth, Meaning of Europe, 1-26.

34 Michael Bauer, 'Dynamic of Enlargement? Europe of the Regions', Osteuropa, 54, 5-6 (2004), 160-79; Michel Huysseune and M. Theo Jans, 'Brussels as the Capital of a Europe of the Regions? Regional Offices as European Policy Actors', Brussels Studies, 16 (2008), 1-11.

35 Farrell, Fella, and Newman, European Integration in the 21st Century, 69-85; Jan Zielonka, Europe as Empire: The Nature of the Enlarged European Union (Oxford: Oxford University Press, 2006), 171-5.

36 David Motadel, 'Nationalist Internationalism in the Modern Age', Contemporary European History, 28, 1 (2019), 77-81; Mark Spoerer, "Fortress Europe” in Long-term Perspective: Agricultural Protection in the European Community, 19572003', Journal of European Integration History, 16, 2 (2010), 143-63.
} 
a more porous, open, and cooperative image of Europe as an epicentre of free trade, an impartial broker and mediator in global relations, and a home of multicultural pluralism and tolerance.

Politically, Europe was first conceived as an equivalent to similarly-sized geographies like the United States, Russia, China, Brazil, or Mexico, many of which are formally 'United States of political unions of culturally disparate subunits. Yet the (chiefly social-democratic or Gaullist) post-Second World War efforts to place Europe on a par with these polities by forging a unified diplomatic thirdparty 'middle way' in global relations (especially as a counterweight to the United States and the USSR) were stymied by the co-option of Europe's constituent nation-states as nation-states into international organisations and institutions (e.g. the UN, NATO, the G7). ${ }^{37}$ In its EU-institutional form, Europeanism has so far remained largely peaceful and cooperative in its external relations, with Europe conceived as an equal trustworthy participant in global institutions and partnerships. In particular, it has largely eschewed global assertiveness, with (e.g.) the reticence of European foreign and security policy counterposed to extensive national (especially British and French) military undertakings; instead, Europe has remained primarily defensive, showing its 'sharp elbows' in the securitisation of its external borders and the Mediterranean, especially in response to the 2014-17 migration crisis. ${ }^{38}$ But this reality obscures a lurking undertow of Europeanisms that envisaged a far more forceful, even brutally aggressive global role for Europe, either in fomenting revolutionary uprisings elsewhere in the world (communist) or as an invading conqueror conducting programmes of resource exploitation, colonial mass resettlement, and ethnic cleansing (fascist, Nazi). Some echoes of this can be seen in non-totalitarian Europeanisms as well, especially in the mooted 'Eurafrican' geopolitics of the interwar and (briefly) post-Second World War period, although this was typically geared towards 'Europeanising' existing European states' colonial empires rather than carving out new ones. ${ }^{39}$

Economically, meanwhile, Europeanism in its first modern manifestations modelled 'Europe' as a reflection of and reaction to plans for internal free trade and external protectionism in the British Empire. ${ }^{40}$ It is striking how widely-accepted protectionist logic soon became among early-twentiethcentury Europeanisms of all ideological stripes, from conservative agrarians to social-democratic trade unionists. ${ }^{41}$ They exhibited a pervasive aspiration to full European autarky, fuelled if necessary by colonial exploitation and motivated by post-First World War fears of excessive reliance for foodstuffs and energy supplies from beyond Europe's borders. ${ }^{42}$ This stands in stark contrast to the far more freetrading logic that has underpinned the trade agreements and partnerships signed since the 1990s by the EU (e.g. the European Economic Area, the Euro-Mediterranean Association Agreement, the Stabilisation and Association Agreements with the Western Balkans, or the Deep and Comprehensive Free Trade Areas with Georgia, Moldova, and Ukraine); contemporary institutional Europeanisms rarely take protectionist measures beyond tariff impositions on trade partners.

37 Christian Bailey, 'The European Discourse in Germany, 1939-1950: Three Case Studies', German History, 28, 4 (2010), 453-78; Anne Deighton, 'The Last Piece of the Jigsaw: Britain and the Creation of the Western European Union, 1954', Contemporary European History, 7, 2 (1998), 181-96; Giuliano Garavini, 'The Battle for the Participation of the European Community in the G7 (1975-1977)', Journal of European Integration History, 12, 1 (2006), 141-58; Jeffrey G. Giauque, 'The United States and the Political Union of Western Europe, 1958-1963', Contemporary European History, 9, 1 (2000), 93-110.

38 Timo Behr, 'Enduring Differences? France, Germany, and Europe's Middle East Dilemma', Journal of European Integration, 30, 1 (2008), 79-96; Celine Cantat, Contesting Europeanism: Discourses and Practices of Pro-migrant Organisations in the European Union (London: University of East London, PhD); Simone Paoli, 'Migration in European Integration: Themes and Debates', Journal of European Integration History, 22, 2 (2016), 279-96.

39 Étienne Deschamps, 'Un rendez-vous historique manqué? La "Petite Europe”, l'Afrique, et le projet de communauté politique Européenne (1952-54)', European Review of History, 6, 2 (1999), 251-63; Robert W. Heywood, 'West European Community and the Eurafrica Concept in the 1950's', Journal of European Integration, 4, 2 (1981), 199-210.

40 Stirk, History of European Integration.

41 Kiran Klaus Patel, ed., Fertile Ground for Europe? The History of European Integration and the Common Agricultural Policy since 1945 (Baden Baden: Nomos Verlag, 2009).

42 N. Piers Ludlow, 'The Making of the CAP: Towards a Historical Analysis of the EU's First Major Policy', Contemporary European History, 14, 3 (2005), 347-71. 
Externally, this comprehensive ideological shift is a response to the emergence of competing transnational economic partnerships (e.g. NAFTA/USMCA, MERCOSUR, ECOWAS, RCEP). Internally, it reflects the rise of liberal and liberal-leaning social-democratic and conservative traditions in EU institutions, due to the successive enlargements to include Britain and later the newly capitalist Eastern European states, and the wider neoliberal turn in the political economy in the 1980s, with the consequent embrace of market liberalisation over state subventions. But one aspect that has remained ideologically unwavering is the clear sense of European cultural 'distinctness' - which some Europeanisms raise to the level of blatant claims of superiority - compared impressionistically to the 'backwardness' (Russia, Africa), 'incompatibility' (Turkey, Asia), or 'vulgarity' (Anglo-America) of Europe's constitutive others. ${ }^{43}$ Europe is a de facto global norm-giver, a position that institutional Europeanism has so far exploited especially (but by no means exclusively) in EU-proximate space. ${ }^{44}$ Yet there are many Europeanisms of several macro-ideological stripes that have strongly advocated for Europe to assert its role as a net producer/exporter rather than consumer/importer of global culture - to the point of pushing for a (re)introduction of Eurocentric one-way cultural-imperial 'instruction' (tied to anti-Americanism, Islamophobia, and Sinophobia, among others).

\section{The Degree of European Consolidation}

The primary concern in Europeanist ideologisation on where 'Europe' might deepen its continental integration is what area of social life efforts to do so should prioritise. ${ }^{45}$ Perhaps the key area of ideological contestation within Europeanist movements during their 1940s-50s heyday, as well as in the bargaining between national governments, was over whether European consolidation should in the first instance be a political, economic, or to a lesser extent cultural endeavour, and how far each of these rival possible 'Europeanisations' is a necessary precondition for realising the others. ${ }^{46}$ While the history of existing European institutions has up to now heavily reflected the economic conception - through organisations and agreements such as the EFTA, the EEA, the EU Customs Union, and the Eurozone - this belies the central role that political and cultural integration played (and still plays) in many Europeanists' accounts of how to constitute a European entity. ${ }^{47}$

It is rare to find Europeanisms that desire a radically different constellation of European political institutions from those that now exist: a parliamentary legislature, executive, judiciary, central bank, currency, etc. ${ }^{48}$ Those that do tend to be totalitarian outliers: their proposed institutions follow either the communist model of a soviet/council republic with closely-imbricated party organisations, or the fascist model of a corporatist party-state centred politically, economically, and culturally on the national hegemon. ${ }^{49}$ Instead, where most Europeanisms diverge is in how they would construct

43 Fioravanzo, 'The Fascist and the National Socialist Concept'; Gosewinkel, Anti-Liberal Europe, 47-71; Wolfgang Kaiser and Antonio Varsori, eds., European Union History: Themes and Debates (Basingstoke: Palgrave Macmillan, 2010), 15068; Brendan O'Connor, 'A Brief History of Anti-Americanism from Cultural Criticism to Terrorism', Australasian Journal of American Studies, 23, 1 (2004), 77-92.

44 Luisa Antoniolli, Luigi Bonatti, and Carlo Ruzza, eds., Highs and Lows of European Integration: Sixty Years After the Treaty of Rome (Cham: Springer, 2018), 11-64; Lorenzo Ferrari, 'The European Community as a Promoter of Human Rights in Africa and Latin America, 1970-80', Journal of European Integration History, 21, 2 (2015), 217-30; Richard G. Whitman, ed., Normative Power Europe: Empirical and Theoretical Perspectives (Basingstoke: Palgrave Macmillan, 2011).

45 Patel, 'Widening and Deepening?'; Jan van der Harst, ed., Beyond the Customs Union: The European Community's Quest for Deepening, Widening, and Completion, 1969-1975 (Brussels: Bruylant, 2007).

46 Cohen, 'Why Call It a “European Community”?'; Michael Gehler, “Europe”, Europeanizations, and Their Meaning for European Integration Historiography', Journal of European Integration History, 22, 1 (2016), 141-74; Schuppert, Pernice, and Haltern, Europawissenschaft, 101-46, 375-574; Wiesner and Schmidt-Gleim, Meanings of Europe, 130-59.

47 Wolfram Kaiser, 'Challenge to the Community: The Creation, Crisis, and Consolidation of the European Free Trade Association, 1958-1972', Journal of European Integration History, 3, 1 (1997), 7-34; Niilo Kauppi, Kari Palonen, and Claudia Wiesner, 'The Politification and Politicisation of the EU', Redescriptions, 19, 1 (2016), 72-90.

48 Antoine Vauchez, 'Statesmen of Independence: The International Fabric of Europe's Way of Political Legitimacy', Contemporary European History, 27, 2 (2018), 183-201.

49 Fioravanzo, 'The Fascist and the National Socialist Concept'; Smith and Stirk, Making the New Europe, 29. 
these institutions (e.g. the electoral system, debt issuance powers, or policy competences), supplemented by additional European-level creations (e.g. Europe-wide, long-range transport and infrastructure, sovereign wealth fund), and to how much of Europe's full geography they would roll them out. ${ }^{50}$ Culturally, however, the history of Europeanism has seen a steady retreat from the early enthusiasm for far-reaching integration. The 1920s-40s saw the strongest push out of any period of major Europeanist output and progress in Europeanisation for harmonisation, ranging from the Esperanto, Ido, and Occidental movements to Second World War-era policies of Germanisation and Umvolkung ('ethnic inversion') in Eastern Europe, and Italianisation of the Mediterranean littoral. ${ }^{51}$ But since then, only very low harmonisation has ever been pursued: all the EU member-states' languages are counted as official languages, while the EU's three working languages continue to be those native to its Western 'core' (English, French, German). ${ }^{52}$

Instead, the dominant logic among Europeanists has been that a large degree of prior economic integration would be needed for other forms of unification to have a realistic chance of success. ${ }^{53}$ In the initial stages of post-Second World War European institutionalisation, the European Coal and Steel Community (ECSC) was designed to provide the necessary cooperative economic groundwork through the creation of a common market and rationalised cross-border industrial production to move onto the priority of political consolidation; only after the European Defence Community failed to achieve ratification in 1954 was the follow-on stage of a European Political Community abandoned. ${ }^{54}$ From a maximalist (federalist) perspective, the reorientation from the Defence and Political Communities to the European Economic Community (EEC) in 1955-7 and the far later, significantly pared-back creation of European Political Cooperation (EPC) in 1970, converted cautiously into the Common Foreign and Security Policy (CFSP) in 1992-7, represented a comprehensive retreat from the original goal of Europeanism. ${ }^{55}$ From a minimalist (sovereigntist) perspective, this shift was a rightful introduction of restraint in the face of incipient overreach. ${ }^{56}$ The same maximalist-minimalist tension subsequently recurred in the debates leading up to the Maastricht Treaty, and the reorientation from the (unratified) European Constitution in 2004-5 to the Lisbon amendments of existing treaties in 2007. ${ }^{57}$ Yet the steady expansion of EP functions and EC policy coverage and specialisation has itself provided the political preconditions for further advances in economic integration (e.g. via debt mutualisation), as well as the future return of plans for political unification.

50 Giuliano Amato, Enzo Moavero-Milanesi, Gianfranco Pasquino, and Lucrezia Reichlin, eds., The History of the European Union: Constructing Utopia (London: Bloomsbury, 2019), 429-560 passim; Emiliano Grossman and Patrick Leblond, 'European Financial Integration: Finally the Great Leap Forward?', Journal of Common Market Studies, 49, 2 (2011), 413-35.

51 Patrick Bernhard, 'Hitler's Africa in the East: Italian Colonialism as a Model for German Planning in Eastern Europe', Journal of Contemporary History, 51, 1 (2016), 61-90; Rodogno, Il nuovo ordine mediterraneo.

52 Oriane Calligaro and Kiran Klaus Patel, 'From Competition to Cooperation in Promoting European Culture: The Council of Europe and the European Union since 1950', Journal of European Integration History, 23, 1 (2017), 129-50; Bernard Esmein, 'Les politiques de l'Union Européenne dans le domaine de la culture, de l'éducation et des langues', Journal of European Integration History, 5, 2 (1999), 75-108; Farrell, Fella, and Newman, European Integration in the 21st Century, 158-201; Thierry Granturco, 'La genèse de l'intégration de la culture au sein des compétences communautaires', Journal of European Integration History, 5, 2 (1999), 109-26; Guy Héraud, 'La communauté Européenne et la question linguistique', Journal of European Integration, 5, 1 (1981), 5-28.

53 Cloet, 'Two Sides to Every Story(Teller)', 292; Erik Jones, 'The Economic Mythology of European Integration', Journal of Common Market Studies, 48, 1 (2010), 89-109; Pierre-Henri Laurent, 'Historical Perspectives on Early European Integration', Journal of European Integration, 12, 2-3 (1989), 89-100.

54 Panos Tsakaloyannis, "The Acceleration of History" and the Reopening of the Political Debate in the European Community', Journal of European Integration, 14, 2-3 (1991), 83-102.

55 Panayiotis Ifestos, 'European Political Cooperation (EPC): Its Evolution from 1970 to 1986, and the Single European Act', Journal of European Integration, 11, 1 (1987), 47-62.

56 Michael Welsh, Europe United?: The European Union and the Retreat from Federalism (Basingstoke: Palgrave Macmillan, 1996).

57 Finn Laursen, ed., Designing the European Union: From Paris to Lisbon (Basingstoke: Palgrave Macmillan, 2012); James Mitchell, 'Understanding Maastricht', Contemporary European History, 5, 2 (1996), 243-57. 
In each of these areas of European intensification, Europeanists also consider the question of what form integration should take; whether it should more take the form of policy cooperation and harmonisation among member-states or the vertical diffusion of sovereignty away from the national level to an alternative unit intended to rival and replace it. Here, the family of Europeanisms offers up a plethora of rival '(neo)functionalist', 'intergovernmentalist', 'supranational', 'statist', and 'multilevel governance' models for the operation of European consolidation mechanisms, which have been extensively explored by various schools of thought in European Union studies in their analysis of European institutions. ${ }^{58}$

Early Europeanist visions were instinctively supranational, or at least non-intergovernmental, in the cases where they conceived of Europe as a 'nation' or state in its own right, or as an empire dominated by (and essentially a 'greater' extension of) a single national hegemon. ${ }^{59}$ But in this, they encountered the same problems as the visions of internationalism circulating in the pre-First World War and interwar periods, namely that realising any sort of European-level integration at all would initially have to overcome the well-established statist and governmental institutionalisation of (European) nations and the borders and differences between them. Setting aside communist models of 'permanent revolution' and soviet-republican reorganisation or fascist imperial expansionism and subordination, if European unification was to be a peaceful process, it would have to rely heavily on national intergovernmental cooperation, even if fostered and informed by transnational Europeanist actors. ${ }^{60}$ Under French pressure in particular - e.g. in the failure of political integration in the 1950s or the protracted 'empty chair crisis' in the 1960s - the stagnation in European institutional evolution helped to recentre and entrench intergovernmentalism as the dominant norm of European interaction as a corollary of member-state equality. ${ }^{61}$ This opened up the European project to ideologies and above all countries (e.g. Britain) whose vision of Europe leaned heavily towards the aggregative and intergovernmental end of the scale, but unsurprisingly stored up tensions for when the growing status and complexity of the EC and EP during the 1980s raised prospects of a resurgence in supranationalism. ${ }^{62}$ The failure to resolve this intergovernmental-supranational tension ultimately allowed the debates for and against a 'federal Europe' in the 1990s and 2000s to grow into a meta-level contestation over the necessity and desirability of Europe tout court by the 2010s.

Europeanist challenges to the prevailing structure of European institutions have accordingly taken the form of rival attempts to drag 'Europe' more decisively towards one or other side of this divide. In this vein, the nuanced positions of 'soft-Eurosceptics' across the ideological spectrum such as the 'anti-euro, pro-EU' line defended by the Alternative für Deutschland (AfD) and others - can be understood more accurately as nation-statist Europeanisms that aim to retard or halt the pull towards supranationalism in favour of further entrenching the conceptual (and institutional) dominance of intergovernmentalism. ${ }^{63}$ Meanwhile, the main supranationalist departures from

58 Christopher Bickerton, European Integration: From Nation-States to Member-States (Oxford: Oxford University Press, 2012); Sergio Fabbrini, Europe's Future: Decoupling and Reforming (Cambridge: Cambridge University Press, 2019), 15-61; Andrew Moravcsik, The Choice for Europe: Social Purposes and State Power from Messina to Maastricht (London: UCL Press, 1998); Kiran Klaus Patel, Project Europe: A History (Cambridge: Cambridge University Press, 2020), 50-83, 176-208.

59 Fioravanzo, 'The Fascist and the National Socialist Concept'; Stirk, History of European Integration.

60 Bruneteau, 'The Construction of Europe'; Wolfgang Kaiser, Brigitte Leucht, and Morten Rasmussen, eds., The History of the European Union: Origins of a Trans- and Supranational Polity (Abingdon: Routledge, 2009).

61 Philip Bajon, 'The European Commissioners and the Empty Chair Crisis of 1965-66', Journal of European Integration History, 15, 2 (2009), 105-24; Mark Gilbert, European Integration: A Political History (London: Rowman \& Littlefield, 2020), 97-104; N. Piers Ludlow, The European Community and the Crises of the 1960s (Abingdon: Routledge, 2006), 118-19.

62 Emmanuel Mourlon-Druol, 'Steering Europe: Explaining the Rise of the European Council, 1975-1986', Contemporary European History, 25, 3 (2016), 409-37.

63 Liesbet Hooghe and Gary Marks, 'Sources of Euroscepticism', Acta Politica, 42, 2 (2007), 119-27; Aleks Szczerbiak and Paul Taggart, Opposing Europe?: The Comparative Party Politics of Euroscepticism (Oxford: Oxford University Press, 2008); Taylor, End of European Integration, 50-69. 
institutional Europeanism aim to 'de-nationalise' Europe's nation-state-based intergovernmental bodies (CEU, EUCO, and the EC's and ECJ's one-member-per-member-state composition), either by reforming their make-up, replacing them with alternatives, or simply eradicating them entirely. The chief alternative constructions mooted for these institutions are then either to (1) 'Europeanise' them by decoupling their personnel composition from the roster of EU member-states and tying their selection to the entity as a whole; (2) 'federalise' them by having them reflect local, meso-, and macroregional geographies, increasing the multilevel nature of European institutions; or (3) 'de-territorialise' them by connecting their make-up (and functions) to non-administrative or even non-political categories.

A closely related issue in Europeanist discourse is 'how many Europes' the plans for unification and integration should lead to. ${ }^{64}$ The initial assumption of almost all Europeanist models was that the various forms of consolidation would ultimately coalesce 'under one roof - i.e. a single European entity with one universal set of institutions. ${ }^{65}$ There is a residue of this in the implicit assumptions of EU enlargement, which treat non-EU European countries (accession candidates and EEA/EFTA members) not as members of a different 'Europe', but as adjuncts or 'members-in-waiting' of the full raft of current and eventual future European institutions. ${ }^{66}$ Yet this monolithic logic has consistently been challenged in the ideological history of Europeanism, giving rise to counter-discourses of overlapping 'Europes' at different 'speeds' of integration, in the form of 'opt-outs' at the 'slower' end and 'enhanced cooperation' at the 'faster' end. ${ }^{67}$

For interwar Europeanisms, the idea of 'one Europe' was superficially self-evident. For these, the whole reason for European unification and integration was precisely that, regardless of their petty local variations, geopolitically and geoeconomically the hitherto rival nation-states of Europe were similarly exposed to the same medium-to-long-term global forces and developmental tendencies. ${ }^{68}$ The first modern Europeanisms thus shared, despite their other extensive differences, a reactive 'join or die' logic that saw achieving fundamental (imperial or federal) unity as the priority, with the introduction of a modicum of structural tolerance for sub-continental variation and divergence something that could be 'fixed' later on once the original existential concern was averted. Certainly, they recognised differential development in different parts of Europe, but they typically saw this as a reason to steer European resources towards fostering the continent's 'backwards' regions to bring them up to 'European' speed - although what this meant to different ideologies ranged from the pluralistic 'European peoples' community' of interwar social democrats to fascist visions of infrastructural investment to help systematically exploit occupied regions' resources with the aim of feeding the (German, Italian, etc.) occupier's global empowerment. However, later Europeanisms completely reversed this logic, in the sense that progress towards greater (not to mention perfect) European unity and integration could only be made if, and insofar as, the 'European settlement' was at every stage constructed in such a way as to leave clear room for national and macroregional divergence. What emerged strongly in the pre-Maastricht Treaty debates, and only more so in the 1990s debates over enlargement, was a clear trade-off between European 'extensity' and intensity, or the 'reach'

${ }^{64}$ Charles C. Pentland, 'Westphalian Europe and the EU's Last Enlargement', Journal of European Integration, 22, 3 (2000), 271-98; Wilson and van der Dussen, History of the Idea of Europe, 140-1.

65 Smith and Stirk, Making the New Europe; Stirk, History of European Integration.

${ }^{66}$ Herbert Brücker, Philipp J.H. Schröder, and Christian Weise, 'Doorkeepers and Gatecrashers: EU Enlargement and Negotiation Strategies', Journal of European Integration, 26, 1 (2004), 3-23; Joseph Lacey and Rainer Bauböck, 'Enlargement, Association, Accession - A Normative Account of Membership in a Union of States', Journal of European Integration, 39, 5 (2017), 529-43.

67 Svein S. Andersen and Nick Sitter, 'Differentiated Integration: What Is It and How Much Can the EU Accommodate?', Journal of European Integration, 28, 4 (2006), 313-30; Jan-Emmanuel de Neve, 'The European Onion? How Differentiated Integration is Reshaping the EU', Journal of European Integration, 29, 4 (2007), 503-21; Kerstin Junge, Flexibility, Enhanced Cooperation and the Treaty of Amsterdam (London: Kogan Page, 1999); Thomas Malang, 'Better = Faster? Explaining Citizens' Desired Speed of European Integration', Journal of European Integration, 39, 1 (2017), 17-31.

68 Stirk, History of European Integration. 
versus 'depth' of consolidation. ${ }^{69}$ In European institutions, bitter contestation took place between rival Europeanist preferences for a smaller, tighter-knit Europe on the one hand, and a larger, looser Europe on the other - contestation that reanimated the distinctions between Europe's 'core' and 'periphery. ${ }^{\text {. }}$. Since then, the compromise mechanism of 'upward convergence' has been used as a way to try to avoid stagnation in European consolidation, in the form of an embedded trend towards generating the conditions for future intensification. ${ }^{71}$ At the same time, institutional Europeanism has been forced to accept the principle of 'variable geometry' as a limit on 'one Europe', with its two most prominent examples restricting Europe's commercial-monetary (euro) and administrative (Schengen) consolidation. ${ }^{72}$

In this context, Europeanist attempts to move beyond their EU-institutional manifestations consist essentially in the aspiration to contest this perceived extensity-intensity trade-off. In particular, such contestation takes aim at the EU's de facto weighting in favour of extensity, and its preference for a 'big tent' of geographical inclusion with certain areas of consolidation remaining unresolved. This may take the form of shifting the balance back towards intensity through a 'concentric circles' logic of 'many Europes', in the form of overlapping geographies at different levels of consolidation, with separate sets of institutions and agreements put in place to manage these different 'circles' - i.e. relations between the regional groupings in each dimension of 'variable geometry'. ${ }^{73}$ This is most prominently associated with proposals to break up the euro into multiple separate 'optimal' currency areas, or to embrace the 'if you don't like it you can leave' logic of Brexit and its potential equivalents for other EU member-states. ${ }^{74}$ Another form of Europeanist contestation here is simply to deny the intensity-extensity trade-off, and argue not only that they can be reconciled but in fact must go hand-in-hand in order for Europe to achieve its purpose - typically associated with far more centralised and homogenised visions of European supranationalism. Or, finally, there is the approach of flatly denying the possibility of ever successfully resolving the trade-off, represented by the impossibilism' of national-sovereigntist Eurosceptics who embrace different degrees of rolling back European consolidation to a more minimal form. ${ }^{75}$

\section{Realising European Consolidation}

On the process of achieving unification and integration, Europeanists differ fundamentally in their treatment of the 'European vision' they aimed for as a matter of pursuing a preordained and a priori evident goal, or of constructing (and, if needed, reconstructing) this goal en route to finding it in a more open-ended fashion. ${ }^{76}$ This tension, which prima facie concerns how Europeanism is realised via various strategic 'Europeanisations' - i.e. ideological moves from theory to practice - also redounds upon the expected content of Europeanism itself. ${ }^{77}$ Europeanism conceived in a proactive sense tends to present 'Europe' as a coherent plan, either (unusually) as a crystalline whole to be manifested

\footnotetext{
69 Frank Bärenbrinker, 'Hallstein's Conception of Europe Before Assuming Office in the Commission', in Wilfried Loth, William Wallace, and Wolfgang Wessels, eds., Walter Hallstein: The Forgotten European? (New York: St Martin's Press, 1998), 82-91.

70 Lars Hallstrom, 'Support for European Federalism? An Elite View', Journal of European Integration, 25, 1 (2003), 51-72.

71 Massimiliano Mascherini, Marina Bisello, Hans Dubois, and Franz Eiffe, Upward Convergence in the EU: Concepts, Measurements, and Indicators (Luxembourg; Publications Office of the European Union, 2018).

72 Farrell, Fella, and Newman, European Integration in the 21st Century, 101-18.

73 Antoniolli, Bonatti, and Ruzza, Highs and Lows of European Integration, 83-102; Fabbrini, Europe's Future.

74 Guglielmo Maria Caporale, 'Is Europe an Optimum Currency Area?: Symmetric versus Asymmetric Shocks in the EC', National Institute Economic Review, 144, 1 (1993), 95-113.

75 Baldassari et al., Anti-Europeanism, 13-29, 77-93.

76 Didem Buhari-Gulmez and Chris Rumford, 'Towards a ("Thick", “Thin”, or "Parallel”) European Society? Understanding the Dynamics of European Multiplicity', Innovation: The European Journal of Social Science Research, 29, 1 (2016), 41-55; Wim van Meurs, Robin de Bruin, Liesbeth van de Grift, Carla Hoetink, Karin van Leeuwen, and Carlos Reijnen, The Unfinished History of European Integration (Amsterdam: Amsterdam University Press, 2018).

77 Gehler, “"Europe”, Europeanizations, and their Meaning'.
} 
immediately, or (more commonly) as a predetermined and predictable series of incremental stages that build intuitively on each other by force of Sachlogik ('material logic') ${ }^{78}$ By contrast, Europeanism in a reactive sense sees its detailed final form as recursively shaped by, and responsive to, the incremental staging-points that mark the progress of Europeanisation; each successive stage is open to ad hoc (re) negotiation, and the 'Europe' that is manifested is a product of stochastic evolution. ${ }^{79}$

The early period of modern Europeanism (especially the interwar period) was marked by such a proliferation of ready-made visions that there was no shortage of available plans to choose from from politicians to bureaucrats, economists to legal scholars, democratic and totalitarian, 'left', 'centre', and 'right' - so that initial contestation was mainly over which plan would be the most appropriate one to pursue in Europe's given economic, political, and cultural circumstances. ${ }^{80}$ But in the post-Second World War 'foundation era', the frustration of several grand institutional proposals by national intransigence, as well as the piecemeal addition of ever more new national actors with whom proposals would have to be squared, fuelled a steadily rising meta-level contestation of the 'plan' approach. ${ }^{81}$ Instead, the contemporary drive for 'ever closer union' is in fact closer to a hybrid of Sachlogik and ad hoc (re)negotiation; at each stage, structural conditions are put in place that mean that future negotiations will likely favour an overall direction that is at least cognate to the one that participants in the previous negotiations had in mind. ${ }^{82}$ Yet this is also subject to the caveat that the authors of (both the original and subsequent) Sachlogik and parties to (re)negotiation continually change their identities over time - not just because of enlargement (e.g. adding in 'Anglo-Celtic' and 'Scandinavian' actors and perspectives), but also due to ideological shifts within member-state governments (e.g. the 1970s social-democratic resurgence, and the 1980s neoliberal, 1990s 'Third Way', and 2010s populist waves). Here the shifting primacy in the exponents of Europeanist ideology becomes especially clear: whereas prima facie it was Europeanist movements and thinkers that formulated coherent plans for Europeanisation, the (re)negotiations that marked its gradual realisation were rapidly taken over by intergovernmental debates, and later engagement between member-state governments and EU institutions. $^{83}$

This turn within institutional Europeanism away from 'grand plans' and towards negotiations that consciously try to start from and cumulatively build on the status quo has also pushed out alternative visions of Europe: both ones that demand greater extensity and intensity as well as ones that demand less. Institutionally, 'the plan' for Europe (insofar as it still exists) continues to be the one set in motion by the treaties of the 1950s, which (re)negotiation can at most modify but never replace. This has left EU-institutional Europeanism unprepared to countenance contestations from not only left- and right-Eurosceptics but also sympathetic Euro-reformists. Here, the crux of ideological contestation is over how stochastic Europe's evolution can be, and what, if anything, is 'beyond the pale' of ad hoc (re)negotiation. The proliferation of agreements adding new competences to institutional Europeanism - i.e. explicitly decontesting areas that were previously held open for later ideological pluralism/struggle - de facto creates the conditions for the emergence of counter-hegemonic Europeanisms that aim to recontest them. This can be seen in the wranglings over the distribution

78 Walter Hallstein, Europe in the Making, Charles Roetter, trans. (London: George Allen \& Unwin, 1972); Henriette Müller, 'The Point of No Return: Walter Hallstein and the EEC Commission between Institutional Ambitions and Political Constraints', Cahiers européens de Sciences Po, 3 (2012).

79 Thomas Christiansen, “Bringing Process Back In”: The Longue Durée of European Integration', Journal of European Integration, 21, 1 (1998), 99-121; Taylor, End of European Integration, 8-23.

80 Stirk, History of European Integration; Weigall and Stirk, Origins and Development, 4-37.

81 Laurent, 'Historical Perspectives'; Jonathan P.J. White, 'Theory Guiding Practice: The Neofunctionalists and the Hallstein EEC Commission', Journal of European Integration History, 9, 1 (2003), 111-32.

82 Andreas Grimmel, 'The Uniting of Europe by Transclusion: Understanding the Contextual Conditions of Integration Through Law', Journal of European Integration, 36, 6 (2014), 549-66; Frank Schimmelfennig, 'European Integration in the Euro Crisis: The Limits of Postfunctionalism', Journal of European Integration, 36, 3 (2014), 321-37.

83 Uwe Puetter, 'Contemporary EU Politics and the New Intergovernmentalism', Journal of European Integration, 38, 5 (2016), 601-15; Uwe Puetter and Sergio Fabbrini, 'Catalysts of Integration - The Role of Core Intergovernmental Forums in EU Politics', Journal of European Integration, 38, 5 (2016), 633-42. 
of European and member-state competences, state aid rules, fundamental rights, internal free movement, and fiscal discipline. ${ }^{84}$

A closely adjacent site of ideological contestation lies in Europeanists' adoption of 'one-shot' or more gradualist approaches to European consolidation. ${ }^{85}$ Europeanisms diverge greatly in their assessment of the pace and scale of Europeanisation that Europe's societies would be able to sustain, or be prepared to accept - i.e. how few or how many stages it would take to achieve full European consolidation, how far apart in time these stages would be, and how substantial an advance in integration each stage would represent relative to its predecessors. ${ }^{86}$ Some err towards a more 'comprehensive' approach, treating each stage as a major qualitative 'reset' of the European economic, political, and cultural order: the formation of 'new Europes' out of the chrysalitic remains of the old. Other Europeanisms take a more 'emendatory' line, drawing a thread of continuity between sequential stages and the precedents they offer for later developments, casting consolidation as merely reformist refinement of the original Europeanist moves.

Europeanism in the interwar and especially post-Second World War context was suffused with the spirit of a momentous 'once in a century' opportunity to permanently reset the dynamics of the European continent. The debates in the lead-up to the 1950s treaties exude an overwhelming sense that Europeanists wanted to achieve as much as possible immediately to (at least) lay strong foundations for future strengthening of the initial form 'Europe' would take. But the subsequent loss of this momentum, due in large part to the intransigence of French Gaullists in the 1960s and British Thatcherites in the 1980s, permanently slowed the tempo of Europeanisation. From an early rate of one to three years between new European treaties in the 1950s, the frequency of new milestones in European integration fell to one every four to five years, with an eleven-year nadir of 'Eurosclerosis' prior to the 1986 Single European Act, and arguably again since 2007; today, the 'European approach' has become stereotypically synonymous with glacial slowness (to the point of unresponsiveness) in updating norms, policies, and structures. ${ }^{87}$ Meanwhile, the 'birth' and evolution of European institutions was a fairly even mixture between setting a general outline initially and leaving the details to be worked out over time, and starting with consolidation in one area of social life then 'working across' to other areas of Europeanisation: first the ECSC and failed European Defence Community (EDC), then the EEC and European Atomic and Energy Community (EAEC); then the ECSC-EEC-EAEC merger; then EPC, then TREVI (the European intergovernmental justice/home affairs network), then Schengen; then intensification under the Maastricht and Amsterdam Treaties into the European Community (Pillar I), Justice and Home Affairs / Police and Judicial Cooperation on Criminal Matters (Pillar II), and CFSP (Pillar III); then finally the 'reshuffling' of competences under the Lisbon Treaty. ${ }^{88}$ These developments took place against a backdrop of severe decline in mass-member Europeanist movements, and a correlative weakening of 'bottom-up' grassroots Europeanist forces. This led to a commensurate reweighting of emphasis in institutional Europeanisation towards (intergovernmental and supranational) 'top-down' elite imposition; in that light, it is possible to see the

\footnotetext{
84 Nathalie Brack, Ramona Coman, and Amandine Crespy, 'Unpacking Old and New Conflicts of Sovereignty in the European Polity', Journal of European Integration, 41, 7 (2019), 817-32; Pentland, 'Westphalian Europe'.

85 Dimitris N. Chryssochoou, 'Europe's Republican Moment', Journal of European Integration, 24, 4 (2002), 341-57; Lynn Dobson, 'Citizenship, Political Authority and Constitutionalism in the European Union: A Normative Theoretical Approach', Journal of European Integration, 23, 4 (2001), 335-71; Bowman H. Miller, 'Tomorrow's Europe: A Never Closer Union', Journal of European Integration, 39, 4 (2017), 421-33.

86 Iain Begg, Annette Bongardt, Kalypso Nicolaïdis, and Franciso Torres, 'EMU and Sustainable Integration', Journal of European Integration, 37, 7 (2015), 803-16; Desmond Dinan, 'The Arc of Institutional Reform in Post-Maastricht Treaty Change', Journal of European Integration, 34, 7 (2012), 843-58; Shivdeep Singh Grewal, 'A Cosmopolitan Europe by Constitutional Means? Assessing the Theoretical Foundations of Habermas' Political Prescriptions', Journal of European Integration, 27, 2 (2005), 191-215; Pentland, 'Westphalian Europe'; Hungdah Su, 'Can Constitution-Building Advance European Integration? A Three-Pillared Institutionalist Analysis', Journal of European Integration, 26, 4 (2004), 353-78.

87 Herbert Giersch, Eurosclerosis (Kiel: Kiel Institute for the World Economy, 1985).

88 Laursen, Designing the European Union.
} 
French and Dutch referendums rejecting the 2005 European Constitution as early warning-signs for the 2010s Eurosceptic-populist backlash. ${ }^{89}$

Attempts to build Europeanism beyond the institutional status quo either seek to extend or realise the latent existing tendencies in (parts of) Europe, or reject them as limiting and embrace 'Europe' as an example of 'new thinking', often using European policy-making to respectively 'upsize' or counteract policy decisions taken at the national or subnational level. In both cases, these attempts typically take the form of expanding the competences of the existing EU institutions: proliferating areas of policy and social activity over which 'Europe' has a say. This can be either vertical or horizontal: i.e. moving EU competences from 'shared' with and 'supporting' member-states to 'exclusive' or developing wholly new institutional dimensions. Normally a degree of both kinds of expansion is required: even radical proposed transformations such as social-democratic accounts of 'Social Europe' and green models for a 'European Green Deal' rely on strengthening the EU part in 'sharing' the relevant competences as well as creating new 'Common Policy' areas (e.g. for employment, welfare, environment, industrial investment). ${ }^{90}$ The dividing questions here are over whether Europeanists believe that such changes can be effected through the development of existing European structures and agreements, or whether they would require a qualitative reconstitution of Europe through new treaties; and over the extent to which the European population is involved at the decisive stages of (de)contesting these changes, for instance via a Europe-wide 'constitutional convention'. ${ }^{91}$

The final area of Europeanist ideological contestation is the extent to which a united, integrated Europe represents the end-point of Europeanists' efforts at transnational collaboration, or whether it is merely a transitional stage to a higher level of global consolidation. ${ }^{92}$ The central ideological consideration here is whether it is possible to identify a point at which Europeanism definitively 'stops' i.e. when Europeanisation has been completed. Some Europeanisms treat it as self-evidently the case that their raison d'être as an ideology is achieved once an economically, politically, and culturally consolidated Europe has assumed its place (however defined) in the global order. Others, however, insist that such narrow Europeanisation does not exhaust the need for an ideology that insists on the distinctiveness of 'Europe' and 'Europeanness', especially in the face of competing pressures for recognition from both higher and lower scales of human interaction and collective identity. ${ }^{93}$

\footnotetext{
89 Sergio Dellavalle, “Top-down” vs. "Bottom-up": A Dichotomy of Paradigms for the Legitimation of Public Power in the EU', Perspectives on Federalism, 9, 2 (2017), 18-46; Ulf Hedetoft, 'National Identities and European Integration "from below”: Bringing People Back In', Journal of European Integration, 18, 1 (1994), 1-28; Roberts-Thomson, 'EU Treaty Referendums'; Richard Rose and Gabriela Borz, 'What Determines Demand for European Union Referendums?', Journal of European Integration, 35, 5 (2013), 619-33; Philip Taylor, 'Public and Elite Support for European Union: Perceptions and Expectations of General Publics and European Community Administrators', Journal of European Integration, 2, 2 (1979), 231-49.

90 Farrell, Fella, and Newman, European Integration in the 21st Century, 135-57; Juliet Lodge, 'Social Europe', Journal of European Integration, 13, 2-3 (1990), 135-50; Mario Pianta and Matteo Lucchese, 'Rethinking the European Green Deal: An Industrial Policy for a Just Transition in Europe’, Review of Radical Political Economics, 52, 4 (2020), 63341; Jonathan Story, 'Social Europe: Ariadne's Thread', Journal of European Integration, 13, 2-3 (1990), 151-65; Taylor, End of European Integration, 147-66.

91 Michael Nentwich and Albert Weale, eds., Political Theory and the European Union: Legitimacy, Constitutional Choice, and Citizenship (Abingdon: Routledge, 1998), 125-40; Johannes Pollak and Peter Slominski, 'The Representative Quality of EU Treaty Reform: A Comparison between the IGC and the Convention', Journal of European Integration, 26, 3 (2004), 201-26.

92 Léonce Bekemans, Globalisation vs Europeanisation: A Human-Centric Interaction (Brussels: Peter Lang, 2013); James A. Caporaso, 'The European Community in the World System: Prolegomena to a Political Economy of the European Community', Journal of European Integration, 2, 3 (1979), 415-40; Laura Cram, 'Introduction: Banal Europeanism: European Union Identity and National Identities in Synergy', Nations and Nationalism, 15, 1 (2009), 101-8; Wilfried Loth, 'Identity and Statehood in the Process of European Integration', Journal of European Integration History, 6, 1 (2000), 19-32; Patel, Project Europe, 231-67; Schmidt, 'Europe and the World'.

93 John Erik Fossum, 'Identity-Politics in the European Union', Journal of European Integration, 23, 4 (2001), 373-406; Gehler and Vietta, Europa - Europäisierung - Europäistik, 197-216, 271-86; Schmale, Geschichte und Zukunft, 13184; Wiesner and Schmidt-Gleim, Meanings of Europe, 194-206.
} 
This aspect of Europeanism is the one that has remained the most extensively unanswered in the historical trajectory of European institution-building, since to a large extent it is simply too early - i.e. Europe is still insufficiently consolidated in itself - to be a major concern for institutional Europeanism. But there are some embryonic signals that point in the direction of Europe taking its place as a member of global institutions, such as through the EU's observer status at the UN and G20, or in the occasional discussions about its taking over the French UN Security Council seat. ${ }^{94}$ This reveals a clear underlying ideological logic to institutional Europeanist practice, which indicates strongly that the prevailing vision of Europe is essentially as a new nation-state member of the 'society of states'. ${ }^{95}$ In other words, EU institutions embrace a version of Europeanism that does not try to eradicate 'methodological nationalism' except within their own geographical borders, and which does not try to prefigure a different way of conducting global relations. ${ }^{96}$ This is surprisingly continuous with several of the interwar Europeanisms, which saw the globe increasingly divided into a series of 'world-empires' (United States, USSR, British Empire, 'East Asia'), and global relations as an arena of emergent pan-nationalisms and continentalisms for which Europe had to find its own equivalent a view that saw a startling degree of homology between fascist, communist, conservative, liberal, and social-democratic advocates of pan- or 'greater' European thinking and identity, expressed with similar levels of nervous consternation. ${ }^{97}$ In both cases, these Europeanisms see internationalism as predominantly a procedural device designed to smooth relations between continental economic-political-cultural units, which carries the implication that 'pure' internationalism is incompatible with Europeanism as well as with other pan-nationalisms. Only rarely can be found examples of 'cosmopolitan' Europeanisms that conceptualise internationalism as creating a global society of peoples and/ or individuals rather than (simply fewer, larger) nation-states. ${ }^{98}$

Correlatively, this aspect is also the Europeanist conceptual element that remains the most open to fantasy, as there still remains extensive scope to contest and differently decontest Europe's place in (and contribution to) the global order. Insofar as they are anti-nationalist, Europeanism and internationalism face the extensively similar problem of wanting to shift away from the prevailing nationstatist form of intergovernmentalism, and both embrace some form of upward diffusion of sovereignty. But countering the EU-institutional Europeanist logic inevitably means finding an alternative to simply reconstituting intergovernmentalism at the continental level. ${ }^{99}$ In this context, Europeanisms can either attempt to weight the intergovernmental-supranational balance within European institutions by simultaneously endorsing the 'fullest' possible instantiation of supranationalism - i.e. globalism - and turning Europeanist efforts towards at least some economic, political, and cultural consolidation at the global level, either alongside or as a supplement for European consolidation. ${ }^{100}$ Alternatively, they can

94 Christine Kaddous, ed., The European Union in International Organisations and Global Governance: Recent Developments (Oxford: Hart, 2015); Albert C. Maes, 'The European Community and the United Nations General Assembly', Journal of European Integration, 3, 1 (1979), 73-83; Taylor, End of European Integration, 110-34.

95 Juliet Lodge, 'Nation-States versus Supranationalism: The Political Future of the European Community', Journal of European Integration, 2, 2 (1979), 161-81; David Marquand, The End of the West: The Once and Future Europe (Princeton, NJ: Princeton University Press, 2011); Wilson and van der Dussen, History of the Idea of Europe, 163-4.

96 Antonio Franceschet, 'Cosmopolitanism, Sovereignty, and the Theory of European Integration: A Kantian Contribution', Journal of European Integration, 21, 2 (1998), 123-46; Glyn Morgan, 'Europe, Europeanism, and European Nationalism', European Political Science, 10, 4 (2011), 501-7.

97 Vinod K. Aggarwal and Edward A. Fogarty, 'The Limits of Interregionalism: The EU and North America', Journal of European Integration, 27, 3 (2005), 327-46; Bernard, 'Matériaux pour une théorie'; Julie Gilson, 'New Interregionalism? The EU and East Asia', Journal of European Integration, 27, 3 (2005), 307-26; Zielonka, Europe as Empire.

98 Bellamy, A Republican Europe of States; Franceschet, 'Cosmopolitanism'; Johannes Dafinger, 'Show Solidarity, Live Solitarily: The Nazi "New Europe" as a "Family of Peoples", European Review of History, 24, 6 (2017), 905-17; Kalypso Nicolaïdis, 'The New Constitution as European "Demoi-cracy"?', Critical Review of International Social and Political Philosophy, 7, 1 (2004), 76-93.

99 Bellamy, A Republican Europe of States; Francis Cheneval and Frank Schimmelfennig, 'The Case for Demoicracy in the European Union', Journal of Common Market Studies, 51, 2 (2013), 334-50; Kalypso Nicolaïdis, 'European Demoicracy and its Crisis', Journal of Common Market Studies, 51, 2 (2013), 351-69.

100 Dunkerley et al., Changing Europe, 157-69. 
select another scale of unit for global-level intergovernmentalism - e.g. between macro- or meso-regions in lieu of nation-states or 'world-empires' - either tout court or alongside existing tiers of sovereignty. ${ }^{101}$ Sometimes, Europeanisms hybridise these two approaches in the form of a 'world federation' comprising a complex array of ascending scales of consolidation, led by more-or-less familiar structures of political organisation, economic management, and cultural identification.

\section{Conclusion}

The historical trajectory of the Europeanist ideological family reveals a striking number of everchanging (re)configurations and (de)contestations of its constituent concepts. This article has examined how different members of this ideological family define its constitutive subject - Europe, Europeanness, and their associated entities - focusing in particular on moments of contingency and fluidity over the course of their evolution, and on the question of the (ir)reducibility of Europeanism to the existence of European institutions. Using the longitudinal account of Europeanism outlined here as a framework to analyse the manifestations, applications, and realisations of this micro-ideology promises to help social-scientific studies of European unification and integration overcome the problematic ahistorical and essentialising tendencies their accounts of Europeanism have often exhibited so far. The family of Europeanisms has undergone a complex and nonlinear evolution in its core concepts and their meaning and valorisation; but in each form, however else they characterise their ideological content, Europeanisms ultimately always return to the central question of defining 'Europe' and 'Europeanness' as the signifiers around which they are built.

101 Mathew Doidge, 'Joined at the Hip: Regionalism and Interregionalism', Journal of European Integration, 29, 2 (2007), 229-48; Michael Gehler, 'The European Union: A Post-Democratic, Post-Modern, and Post-National Empire?', Journal of European Integration History, 24, 2 (2018), 235-68; Panayotis Soldatos and Hans J. Michelmann, 'Subnational Units' Paradiplomacy in the Context of European Integration', Journal of European Integration, 15, 2-3, 129-34; Fredrik Söderbaum and Luk Van Langenhove, 'The EU as a Global Actor and the Dynamics of Interregionalism: A Comparative Analysis', Journal of European Integration, 27, 3 (2005), 365-80.

Cite this article: Ostrowski MS (2021). Europeanism: A Historical View. Contemporary European History 1-18. https:// doi.org/10.1017/S0960777321000485 